"We believe that there is in the West, among professors and others who are paid, in principle, to think and teach, a new and systematic flight from science and reason," Gross declared at a meeting in 1995 at the New York Academy of Sciences. He added for good measure that this flight had "brought with it a truculent defence in the name of 'democracy' of New Age and traditional sophistry and charlatanism" (see Nature 375, 439; 1997).

Such rhetoric may not have done much to bridge the divide between the two cultures. But it certainly convinced some scientists that the best way to defend science was to attack its critics. One such was Alan Sokal, a physicist at New York University. Inspired, he says, by Gross and Levitt, Sokal raised the ante of the debate with a now-celebrated hoax, in which he planted a ludicrous article about quantum theory in Social Text, a sociology journal.

Defending the hoax later in the New York Review of Books, Weinberg said Sokal had

performed "a great service" by raising the profile of the debate. "We will need to confirm and strengthen the vision of a rationally understandable world if we are to protect ourselves from the irrational tendencies that still beset humanity," he thundered. But

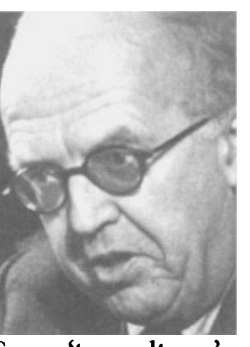
Snow: 'two cultures' gap still remains.

the Sokal hoax has been decried by many social scientists as going beyond the bounds of fair play. "I don't think discussion is furthered by poking fun at people," says one sociologist.

Collins makes a broader comment about the beginnings of the debate. "In the early days, it was as if we were entering this native village, and all the guard dogs came out and started biting our ankles," he says. "It was a mistake to

\title{
Science studies braces for the fall-out
}

The Science Wars debate has sent a chill wind through a corner of the academic world that is more used to operating out of the limelight - namely the discipline known loosely as 'science and technology studies' or STS.

Critics of the area, which has struggled to establish its academic legitimacy ever since various universities decided in the late $1960 \mathrm{~s}$ that scientists should be taught about the social implications of their work, argue that this wind should be seen as a breath of fresh air.

But many of those professionally involved prefer to talk in terms of witchhunts, scapegoats and misunderstandings, arguing that they are being required to pay the price of a few youthful indiscretions, and are being unfairly blamed for social attitudes towards science whose origins lie elsewhere.

So far, the fall-out has been mostly anecdotal and focused on individuals. It is being widely claimed, for example, that the black-balling of a prominent historian of science, Norton Wise, from his appointment to the faculty of the Institute for Advanced Study at Princeton University, has been linked to his involvement in the so-called 'Sokal affair' (see page 325).

But there is little doubt that those responsible for teaching courses in the field feel that the tone of the debate has put them and many of their colleagues on the defensive. "The whole thing is creating an intense nervousness in our community," says Steven Shapin, a member of the original 'Edinburgh school' (see opposite) who now teaches the history and sociology of science at the University of California, San Diego.

Others claim more direct antipathy to their efforts. Tom Gieryn, for example, of the department of sociology at Indiana
University, said that the American Chemical Society, as sponsor of a controversial exhibit on Science in American Life at the Smithsonian Institution in Washington, had tried "to remove every mention of social science from the exhibition", for which he had been a consultant.

Gieryn was speaking at a meeting organized two weeks ago by the department of science and technology studies at Cornell University, the only US university to offer a full undergraduate degree in science and technology studies. Sheila Jasanoff, the chair of the department, points out that, even if the Science Wars debate is not having a direct impact at the institutional level, the fall-out from it may already be influencing funding decisions.

"When money is tight, you tend to cut out the things that are considered non-essential," says Jasanoff. "The curriculum in academic life is becoming more market driven than 'intellect' driven. The sociology of scientific knowledge is an easy thing to target, and appears to stand for a lot of things that some people say are going wrong in society."

The demand for such courses is still strong among undergraduates. Protests from students were a key factor that helped persuade Stanford University last year to make available an extra tenured position, to avoid having to close its interdisciplinary STS programme (see Nature 383,$563 ; 1997$ ).

Jasanoff also claims that growing links are being forged between individuals trained in STS-related topics - for example in studies of the public perception of risk, or of the status of scientific evidence and expertise - and those engaged in confronting such issues in a practical way in political and legal arenas. try to have a discussion with the guard dogs."

But Sokal's activities have undoubtedly helped to broaden the issue, which has even found its way into the columns of Newsweek magazine. Now, at meetings across the United States, an increasing number of academics are joining in. Earlier this year at the University of Kansas, Lawrence, for example, more than 200 staff and students showed up to hear Sokal defend his unconventional tactic.

"I didn't have to invent anything" to produce the hoax, Sokal explains. "I simply quoted the post-modernist masters and showered them with praise." He admits that the success of the hoax proves nothing, except that one journal should more carefully review what it publishes. But Sokal has used the notoriety of the hoax to build a broader case against what he brands "the sloppy thinking and glib relativism that have become prevalent in many parts of science studies".

One of the sociologists attacked by Sokal and Gross, Steve Fuller, professor of sociology at the University of Durham in the United Kingdom, went to the Kansas meeting to defend science studies. "I won't deny that some people are in this to bash science - but only a very few," says Fuller.

Fuller argues that the idea of 'progress' in science and technology is a passing fad, which arose with the Enlightenment and is now diminishing as society realises that science and technology will not solve the problems that people used to hope that they would.

\section{Converging on truth}

This is one of the points at which dialogue between science and its critics breaks down. Most scientists do indeed believe that they are making absolute progress towards understanding nature. They think that the scientific method renders their knowledge quite distinct from other bodies of knowledge - such as the study of history, for example - where absolute truth is elusive, and the characters of the people involved and their chosen ways of working clearly play a major role in the direction ideas take.

Adrian Melott, a physicist at the University of Kansas, points out that scientists see the most important form of progress as being that of "convergence on the truth". He told Fuller: "You seem to view that as a defunct concept. I don't buy that. It is clear that we understand natural reality better than our predecessors did."

Sokal joined in on the attack: "Do you think that physics has made any progress in the last 300 years?" Fuller seemed to stall. "From our standpoint, yes; but could you convince these people [of Galileo's era] that you had advanced on what they'd done?" For most of the scientists in the room, the answer was obviously "yes".

But if the case for scientific progress remains strong, its presentation - through Gross, Levitt and Sokal in particular - has 